NBER WORKING PAPER SERIES

\title{
COPING WITH SHOCKS AND SHIFTS: \\ THE MULTILATERAL TRADING SYSTEM IN HISTORICAL PERSPECTIVE
}

\author{
Douglas A. Irwin \\ Kevin H. O'Rourke \\ Working Paper 17598 \\ http://www.nber.org/papers/w17598 \\ NATIONAL BUREAU OF ECONOMIC RESEARCH \\ 1050 Massachusetts Avenue \\ Cambridge, MA 02138 \\ November 2011
}

This paper was prepared for the Bank of England/NBER conference on Globalization in an Age of Crisis:Multilateral Economic Cooperation in the Twenty-First Century, London, September 2011. We are grateful to participants at the conference, and in particular to Alan Taylor, for helpful suggestions. The research leading to these results has received funding from the European Research Council under the European Union's Seventh Framework Programme (FP7/2007-2013) / ERC grant agreement no. 249546. O'Rourke thanks the ERC for their generous support. The usual disclaimer applies. The views expressed herein are those of the authors and do not necessarily reflect the views of the National Bureau of Economic Research.

NBER working papers are circulated for discussion and comment purposes. They have not been peerreviewed or been subject to the review by the NBER Board of Directors that accompanies official NBER publications.

(C) 2011 by Douglas A. Irwin and Kevin H. O'Rourke. All rights reserved. Short sections of text, not to exceed two paragraphs, may be quoted without explicit permission provided that full credit, including (C) notice, is given to the source. 
Coping with Shocks and Shifts: The Multilateral Trading System in Historical Perspective Douglas A. Irwin and Kevin H. O'Rourke

NBER Working Paper No. 17598

November 2011

JEL No. F02,F13

\section{ABSTRACT}

This paper provides a historical look at how the multilateral trading system has coped with the challenge of shocks and shifts. By shocks we mean sudden jolts to the world economy in the form of financial crises and deep recessions, or wars and political conflicts. By shifts we mean slow-moving, long-term changes in comparative advantage or shifts in the geopolitical equilibrium that force economies to undergo disruptive and potentially painful adjustments. We conclude that most shocks (financial crises and regional wars) have had relatively little effect on trade policy, but that shifts pose a greater challenge to the system of open, multilateral trade.

Douglas A. Irwin

Department of Economics

Dartmouth College

Hanover, NH 03755

and NBER

douglas.irwin@dartmouth.edu

Kevin H. O'Rourke

All Souls College

Oxford University

Oxford OX1 4AL, UK

and NBER

kevin.orourke@all-souls.ox.ac.uk 


\section{Coping with Shocks and Shifts:}

\section{The Multilateral Trading System in Historical Perspective}

\section{Introduction}

How can multilateral cooperation on matters of trade policy be sustained? How has the multilateral trading system been able to cope with the various challenges that have confronted it in the past? The goal of this paper is to see if history can provide us with guidance in dealing with the challenges in maintaining open, multilateral trade in the years ahead. These challenges are non-negligible in light of the prolonged economic fallout from the financial crisis of 2008-9, the rapid rise of China as a major exporter, and the apparent failure of the Doha Round.

The paper focuses on the extent to which policymakers have been able to construct a multilateral trading system, and how the system has (or has not) responded to the major challenges that confront it. We draw attention to two broad categories of challenges: shocks and shifts. By shocks we mean sudden jolts to the world economy that can take the form of financial crises and deep recessions, or wars and political conflicts. By shifts we mean slow-moving, long-term changes in comparative advantage or shifts in the geopolitical equilibrium that force economies to undergo potentially painful and disruptive adjustments.

To analyze the consequences of these shocks and shifts, we need a framework. Ours is based on Aesop's fable of the oak and the reed:

"You have reason to complain," said the Oak. "The slightest breeze that ruffles the surface of the water makes you bow your heads, while I, the mighty Oak, stand upright and firm before the howling tempest."

"Do not worry about us," replied the Reeds. "The winds do not harm us. We bow before them and so we do not break. You, in all your pride and strength, have so far resisted their blows. But the end is coming."

As the Reeds spoke a great hurricane rushed out of the north. The Oak stood proudly and fought against the storm, while the yielding Reeds bowed low. The wind 
redoubled in fury, and all at once the great tree fell, torn up by the roots, and lay among the pitying Reeds. ${ }^{1}$

This fable points to the need for shock absorbers if a trading system is to survive. Some international regimes have been characterized by a greater variety of shock absorbers, or more efficient ones, than others. This can help to explain their relative longevity. At the time of writing, our own period's trading system seems reassuringly reed-like, while the reconstructed international system of the 1920 s proved to be a bit of an oak. Indeed, the liberal international order of the $19^{\text {th }}$ century also turned out to be an oak: while the period saw the development of various economic shock absorbers, in the end its geopolitical shock absorbers proved inadequate.

Before describing the ways in which the multilateral trading system can be preserved, we need to define what it is. We begin by discussing the various features of a multilateral trading system that are generally considered to be desirable. There are a number of aspects of a multilateral order, not all of which are consistent with one another, that policymakers have professed to be worthwhile goals. Section 3 examines the history of the international trading system over the past two centuries, focusing on where it has come close to and where it has deviated from the desiderata set out in section 2. Section 4 discusses and classifies the shocks and shifts to which the international economy has been subjected over the past two centuries. Section 5 briefly compares today's shock absorbers to those of the past. Section 6 applies the lessons of history to ask where the international economy goes from here.

\footnotetext{
${ }^{1}$ Anonymous (1919).
} 


\section{Free trade and multilateralism}

Robert Keohane (1990) has defined multilateralism as "the practice of coordinating national policies in groups of three or more states," to which other political scientists have added that the coordination take place on the basis of certain agreed-upon principles. ${ }^{2}$ A multilateral system of world trade, therefore, refers to the cooperative efforts of various countries in the realm of trade policy. Since countries do not need to cooperate with each other to increase trade barriers and diminish trade (something they can manage quite well on their own), the goal of such cooperation is usually to reduce trade barriers and expand trade. For example, the purpose of the 1947 General Agreement on Tariffs and Trade (GATT) is to undertake "reciprocal and mutually advantageous arrangements directed to the substantial reduction of tariffs and other barriers to trade and to the elimination of discriminatory treatment in international commerce ... with a view to raising standards of living, ensuring full employment and a large and steadily growing volume of real income and effective demand, developing the full use of the resources of the world and expanding the production and exchange of goods.”3

Thus, a multilateral system is a means to an end, the end being a growing world economy and all the benefits that flow therefrom. Does such a system require institutional arrangements such as we have today? After all, one might argue that an idealized world with no trade agreements but universal free trade would also constitute a multilateral trading “system.” Before considering whether institutional arrangements are required to have a multilateral system, it would be useful to consider the desirable properties of such a system.

\footnotetext{
${ }^{2}$ Political scientists have traced the first use of the term "multilateral" in the context of an international system back to 1858. The term multilateralism came into use after World War I.

${ }^{3}$ Preamble to the GATT 1947. http://www.wto.org/english/docs_e/legal_e/gatt47_01_e.htm
} 
First, a multilateral system of trade should be open. Openness has several dimensions. One is that countries should have access to each others' markets. This does not necessarily mean free trade in its purest sense, but that government-imposed barriers or hindrances to trade be kept within some defined limits. Another dimension is inclusiveness, that the system be open to the participation of all countries who are willing to abide by the terms agreed to by others. This usually means non-discrimination, that the system not be an exclusive club, or that the mostfavored nation (MFN) clause has wide applicability.

Second, a multilateral system of trade should be stable. Once again, stability has several dimensions. One is that government trade barriers be predictable or reasonably certain to the entities engaged in trade. No country would want to see its exports suddenly shut out of foreign markets because of an abrupt and unanticipated change in import duties or quotas. This would be disruptive to world commerce and would stifle trade to the extent that it increased uncertainty about the terms on which trade can take place. How can this certainty be provided? This may require formal or informal "rules of the game" taking the form of informal norms or explicit trade agreements.

Another dimension of stability is that the system should have a well-functioning adjustment mechanism. This chore is usually performed by the international monetary or financial system. Trade should not be conducted and balanced bilaterally, but rather the system of payments should facilitate multilateral trade. An example of such a system at work is provided by Figure 1, which gives a stylized representation of the world trade settlements system in 1910. As can be seen, the international trading system on the eve of World War I was a multilateral one, in the sense that countries ran up trade surpluses with some partners which they then used to finance deficits with other. For example, India ran a large trade deficit with the United Kingdom, 
but ran surpluses with continental Europe, the United States, Japan and China. The United Kingdom, meanwhile, used its surpluses with India and other countries to finance its deficits with continental Europe and the United States.

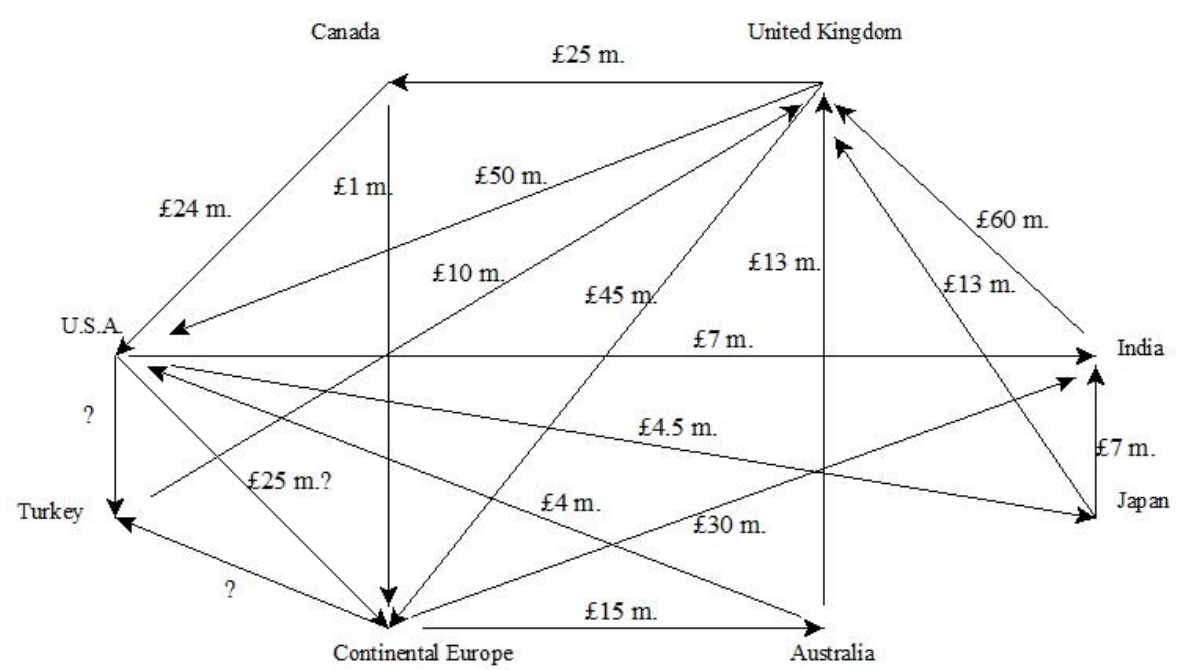

Figure 1. World Pattern of Settlements, 1910

Source: Saul (1960, p. 58).

The polar opposite to a multilateral trading system, in this sense, is a bilateral trading system in which pairs of countries engage in what essentially amounts to barter trade, balancing trade on a bilateral basis. This is not just a theoretical curiosum, since something along these lines has been observed on several occasions over the past century. Communist countries often resorted to barter-style arrangements, for example, in order to keep their domestic price systems insulated from world market conditions, and so did the Nazis when dealing with their informal empire in Southeastern Europe during the 1930s. More prosaically, Western European countries typically had inconvertible currencies after 1945, and it took the establishment of the European 
Payments Union to bring about a properly multilateral trading system during the 1950s. The economic advantages of multilateralism in this sense are obvious and large, since they are the same as the advantages of trade financed by money relative to barter.

Yet another aspect of stability is flexibility in the face of shocks. If rules are written to maintain openness, the question is whether openness can be preserved in times of stress when there are pressures to deviate from the open regime. If the pressures are not accommodated to some degree, and find no other outlet, the system could break, as Aesop's fable reminds us. If the pressures are too easily accommodated, because the system has safety valves, the system may not remain very open. This balancing act lies behind the "escape clause" (Article XIX) of the GATT, which allows countries to restrict imports of goods that threaten serious injury to domestic producers. If interpreted too strictly, it is no escape clause at all; if interpreted too loosely, there will be no discipline in the use of trade restrictions. An optimal mix of rules and flexibility is required in order to make sure that countries agree to join and to remain in a rulesbased system, and that those rules effectively discipline behavior. Similarly, there is an optimal mix between the need to constrain individual states' freedom of action, in the interests of all, and the need to respect national sovereignty and democracy (Rodrik 2011).

Many would also consider fairness to be a desirable attribute of an international trading system. For example, it would not seem fair to many if powerful countries extracted numerous trade concessions from weaker countries without providing much in return. The need for fairness is operationalized via the concept of reciprocity in WTO trade negotiations. Another desirable property of such a system is that trade disputes be settled by negotiation or arbitration, rather than by the use of unilateral economic sanctions or actual violence. Warfare is the antithesis of a multilateral trading system, since during wars states try to prevent their enemies from exporting 
(in the case of a mercantilist war) or importing (in more modern wars). Furthermore, the fear of such embargos, or pre-emptive embargoes in anticipation of war, can be an important factor leading to war in the first place. The WTO tries to satisfy the need for peaceful resolution of trade conflicts through its dispute settlement system of arbitration.

The next question is whether these goals - openness with deference to national sovereignty, stability with built-in flexibility, and so forth - can only be achieved through an institutional multilateral structure. Why is a multilateral trading system necessary, as opposed to having each country determine its own trade policy by itself without interference from others?

It is not immediately obvious whether such a system needs to be "created" by policymakers or whether it can arise spontaneously without formal coordination. Many countries have unilaterally chosen policies that conform to these desirable outcomes. In a model with a high initial level of tariffs, most of the features of the current trading system—multilateral negotiations, gradual liberalization, reciprocity, and MFN—can develop endogenously, according to Ethier (2004), if government behavior is dictated by a political support function consistent with how governments claim to behave, and if reasonable substitutes for each country's exports are produced elsewhere.

Yet, as we shall see, historical experience suggests that such good behavior may not arise automatically and spontaneously from countries choosing their own trade policies independently of one another. An institutionalized multilateral system may be necessary to achieve the goals of free and open trade. Without a multilateral system in place, countries may pursue selfish, mercantilist, beggar-my-neighbor policies without regard to the welfare of their trading partners, 
and the world as a whole may find itself stuck in a Prisoner's Dilemma. ${ }^{4}$ Or perhaps, without the benefit of external constraints, policymakers may succumb to domestic interest groups and impose trade restrictions that are detrimental to the country itself, as well as to others. Therefore, without international agreements on trade policies, countries may pursue policies that restrict trade either to redistribute income to their own country at the expense of others (beggar-myneighbor policies, as modeled by Bagwell and Staiger 2002) or to redistribute domestic income to politically powerful groups (beggar-myself policies, as modeled by Maggi and RodriguezClare 1998).

In either case, countries have self-interested reasons for reducing trade that can only be overcome to the betterment of all if they agree to refrain from those trade-restricting policies. Thus, a multilateral trading system may be needed to correct these externalities (terms of trade or domestic politics); without an institutionalized system, the world economy will not flourish as much as it could.

\section{1860 and all that: a brief history of the international trading system}

To what extent has the world trading system conformed to these features of a desirable multilateral system? To what extent have government worked to create such a system with these goals in mind? We examine four different historical epochs: the mercantilist period (between 1492 and the early nineteenth century), the nineteenth century order (lasting until 1914), the interwar period (from 1919 to 1939), and the post-war system of the GATT and the WTO (from 1947 to the present).

\footnotetext{
${ }^{4}$ The analogy is appropriate if countries can benefit from their own protectionist policies, which is true in certain modeling environments, but not in others.
} 


\section{The Mercantilist Era}

Broadly speaking, the international trading system between 1492 and the Industrial Revolution can be described as 'mercantilist'. There are several key features of this system, or perhaps non-system, which are relevant for us.

First, the geopolitical system of the time was essentially Darwinian. The Military Revolution of the period implied rising military costs, and conferred substantial advantages on larger countries, as well as on countries which were more efficient in raising revenue. The costs of not remaining militarily competitive included extinction, and the number of sovereign states within Europe declined substantially during the period.

Second, trade and colonization were seen as important means by which states could raise revenue. Aside from the obvious benefits of plunder, monopolizing particular trades could lead to substantial profits for merchants and sovereigns. Monopoly trading companies were thus established, with the active support of the State, and their attempts to monopolize were backed with military force. Because of these links between military force, monopoly, and profits, there was a two-way inter-relationship between Power and Plenty (Viner 1948): Plenty was essential for Power (as remains true today), while Power was thought to be essential in securing Plenty (something which is no longer the case, whether or not it was in fact then). The result was a series of wars in Asia and America, fought between Europeans in order to establish who would manage to secure for themselves these trading profits.

It is certainly possible to argue that these wars were mutually destructive, and that Europe (and the world) would have been better off without them. For example, in equilibrium it may well have been that the military costs invested in establishing trading monopolies equaled (on average) the profits which these monopolies yielded: States would then have been left with no 
net revenue benefit, while the world as a whole suffered the costs of war and a fragmented trading system. Indeed, when military gambles went wrong, this could have a catastrophic impact on state finances, with revolutionary consequences. Unfortunately, such considerations might not have been of much practical use to an individual monarch contemplating a unilateral move to peaceful free trade, since his exclusion by force from trades in which his merchants had previously been involved might have been a logical consequence of such a decision. States were thus locked into a Prisoner's Dilemma of sorts, and there was no multilateral geopolitical framework to help them escape the trap.

Third, the technological environment helps to explain why inter-continental trade was monopolized by state trading companies backed by military muscle. Transport costs were still high, with the result that intercontinental trade typically involved goods with a high value to weight ratio (O’Rourke and Williamson 2002). High prices reflected scarcity in Europe - often caused by a complete absence of locally produced supplies - and thus the prospect of monopoly profits.

This mercantilist world was destroyed by the victory of the United Kingdom, as she was by then, in 1815, and by the forces set in motion by the Industrial Revolution. Population growth and industrialization led to the Britain becoming a large net importer of food: this gave the country a powerful interest in keeping the sea lanes of the world open for trade. The Royal Navy was sufficiently dominant that it was able to provide the world with this public good, while the Congress of Vienna established a remarkably durable peace within Europe. The war led to the dismantlement of the Iberian empires in Latin America, and the mercantilist trade restrictions that had been associated with them. It also led to the destruction of the Dutch East India Company, and to the loss of the monopoly on the Indian trade which had been enjoyed by its 
English counterpart. The Industrial Revolution, meanwhile, eventually led to a dramatic reduction in transport costs which made possible the mass transport of bulky, 'competing' commodities across the oceans of the world. Trying to monopolize the trade in a good like pepper was difficult enough; trying to monopolize the trade in basic food grains would have been merely silly.

\section{The Nineteenth Century Order}

The end of the mercantilist era heralded a movement toward a much more open and nondiscriminatory trade regime. Movement in this direction hinged largely on the policy choices of Britain, the world's largest trading economy. In terms of its immediate post-Napoleonic war commercial policy, however, Britain was split: it sought to protect aristocratic landowners from foreign competition (by enacting the Corn Laws in 1815 to limit imports of wheat) while also seeking trade agreements to open foreign markets for its burgeoning manufacturing sector.

Of course, these policies conflicted: unless Britain was willing to open its market to foreign agricultural produce, other countries were unlikely to want a trade agreement allowing Britain to export more of its manufactured goods to their own markets. Other countries lacked a strong domestic constituency in favor of liberalization and, moreover, were suspicious of Perfidious Albion's motives. Britain failed to convince other countries that it was in their interests to set aside their own ambitions to become a manufacturing power and simply follow the logic of Smith and Ricardo, and import Britain's industrial goods. Hence, Britain's early efforts to conclude reciprocity agreements failed miserably.

This failure had lasting consequences: more than a generation of British trade policymakers concluded that it was futile and even counterproductive to attempt to persuade 
other countries to adopt freer trade. When the Irish potato famine occurred during Sir Robert Peel's reform-oriented prime ministership, Britain unilaterally abolished its Corn Laws without using the repeal as a bargaining chip with other countries. Henceforth, Britain opted for unilateral trade policies, leaving it to other countries to choose for themselves their own best policy. (This even applied to Britain’s self-governing colonies, such as Australia and Canada, which were permitted to impose stiff duties on British manufactured goods.)

While it could not use its clout to influence European tariff policies, Britain did use its power to open up markets in Turkey, China, Japan, Persia, and several Latin American states. However, it did so on an MFN basis, open for all other countries to participate. Britain never sought preferential access for its exports, either with Europe or with weaker powers in Latin America and Asia.

The decision to remain aloof from commercial bargaining was so deeply instilled in Britain that it nearly scuttled the Cobden-Chevalier treaty of 1860. This Anglo-French trade agreement was pursued largely for diplomatic rather than commercial reasons, but was negotiated on the British side by Richard Cobden rather than the Board of Trade so that British diplomats did not have to sully their hands with the dirty business of trade. Chancellor of the Exchequer William Gladstone used this opportunity, in his famous 1860 budget, to do a thorough housecleaning of the British tariff code, going far beyond the agreement itself. Britain insisted that all the negotiated and unilateral tariff adjustments would be extended to other countries pro bono, on an unconditional MFN basis, without any thought being given to using the changes to extract trade concessions from others. Thus, nineteenth century Britain firmly rejected the "GATT-think” of today, which views giving market access to imports as a "concession” and receiving market access for one’s exports as a "benefit." 
France, by contrast, reduced its tariffs on British goods alone; if other countries wanted the same rates, they would have to cough up some concessions of their own in a separate bilateral deal. And that is precisely what happened: other countries began negotiating trade agreements with France, which in turn led to further trade agreements with each other. This patchwork of bilateral trade agreements, with MFN clauses and some tariff concessions, led to the creation of an informal trade treaty network during the mid-nineteenth century. There was no multilateral structure behind the bilateral agreements. The agreements led to trade liberalization in certain product categories, but not to free trade as practiced by Britain at this time (Lampe 2009).

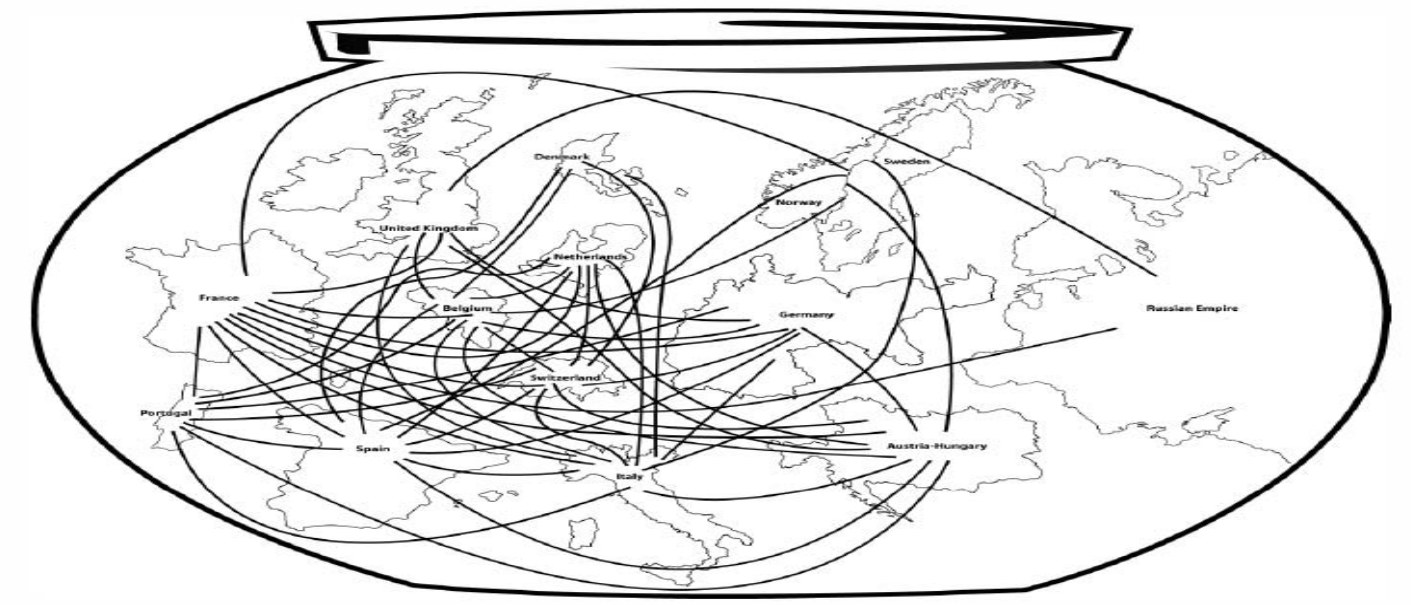

Note: Lines represent unconditional MFN-PTAs signed between 1857 and 1875, as in Lampe, 'Bilateral trade flows', app. 2; the map is based on IEG/A. Kunz, Europa 1871, at http://www.ieg-maps.uni-mainz.de.

Figure 2. The 'Mother of All Spaghetti Bowls': The Cobden-Chevalier Network in 1875 Source: Lampe (2011), Figure 1, p. 645.

The nineteenth century treaty network was a remarkable, spontaneous development that promoted multilateral trade. It was a system open to any country that sought to participate in it, 
and it led to the widespread use of the MFN clause. However, it fell short of satisfying all the desirable attributes of a multilateral system. The treaty network was confined almost exclusively to Europe, as the United States was not in a position to bargain over its trade policy. Indeed, outside of Europe, protection was high wherever local populations were free to choose their own policies. Where they were not free to choose, free trade was sometimes imposed upon them, inconsistent with the desirability of respecting national sovereignty and democracy. Furthermore, the reduction in trade barriers as a result of the agreements was limited because of domestic political considerations, as well as revenue constraints.

Finally, the informal network was not very robust. In terms of its ability to cap trade barriers, it proved to be rather short lived, from about 1860 until the mid-1870s, when tariff levels started rising again. The problems began in the aftermath of the Franco-Prussian war and the financial crisis of 1873, when the world economy experienced a prolonged slowdown. ${ }^{5}$ This prompted many countries to allow the tariff reductions in their time-limited commercial agreements to lapse, and even led to general tariff hikes in a number of countries.

Similarly, the decline in European grain prices caused by an expansion of overseas production and declining transport costs placed land rents under pressure, and sparked a protectionist backlash among agricultural interests (O’Rourke 1997). France came close to abandoning the Cobden-Chevalier treaty altogether; although it agreed to extend it until 1877, all the French tariff concessions were gone by 1882 when duties were increased. Germany imposed the "iron-and-rye" tariff of 1879, and others followed similarly. Although the MFN clause

\footnotetext{
${ }^{5}$ The period 1873-1877 has sometimes - misleadingly - been called "the Great Depression;" it was an era of falling prices but not falling output, although the economic expansion was at a slower pace than before.
} 
remained largely intact, European tariffs generally increased from the late 1870s until the early 1890s. The resulting friction produced frequent bilateral trade spats between countries.

The nineteenth century treaty network turned out to be fragile because governments had not agreed to many commitments that constrained state action. And governments had recourse to few alternative domestic policies to address the economic problems of the day. Many governments relied on import duties to raise revenue, making higher tariffs a way of dealing with budget shortfalls. Subsidies to firms and unemployment insurance for workers were not yet part and parcel of government policy. (In those countries which introduced social insurance schemes earlier, trade policies generally remained more open; see Huberman and Lewchuck 2003.) The gold standard, which also arose at this time, facilitated trade by keeping exchange rates fixed but also prevented the use of monetary policy to address the economic downturn. Hence, mindful of their electorates, policymakers resorted to higher tariffs as a way of dealing with the economic problems of the period.

Britain woke up to the fact that the market access it had taken for granted was now being limited. In 1875, in the bowels of the Foreign Office, some officials conceived of a diplomatic initiative for a European tariff union. However, Britain's unilateralist instincts were still too strong, and few envisioned that the project could be a success, so it was never pursued (Gaston 1987). Thus, the one time that Britain could have shown leadership in attempting to provide a multilateral framework for trade policy, it shrank from the task.

It must be stressed, however, that despite the relapse in commercial policies that left the mid-nineteenth century treaty network in shambles, trade costs continued to fall, the world economy began to boom, and world trade prospered in the two decades prior to 1914. The increases in tariffs were not enough to offset the impact of railroads and steamships in reducing 
transport costs, and overall trade costs fell. Not only commodity trade, but factor movements, boomed in the decades immediately preceding the outbreak of World War I (O'Rourke and Williamson 1999).

\section{The Interwar Period}

The nineteenth century order came to an end in 1914 with the outbreak of World War I. This conflict severely disrupted world trade, particularly as the war extended to commercial shipping. The conflict also led to widespread restrictions on trade, with limitations on imports imposed to conserve on foreign exchange and to build up domestic defense-related industries.

The long run consequences of the war were even more important (see, for example, Eichengreen 1992 or Findlay and O’Rourke 2007). The Congress of Versailles was as unsuccessful in establishing a stable postwar order as the Congress of Vienna had been successful. Wartime debts and reparations poisoned international relations, and led directly to the hyperinflations and payments imbalances of the 1920s which would have such a damaging effect. The Russian Revolution of 1917 not only contributed significantly to interwar international tensions; as noted earlier, the nature of the Communist economic system meant that it also had a profound disintegrating influence on the international economy - which only finally ended in the 1990s. The Austro-Hungarian empire had collapsed, and there were new states in the Baltic region and in Central Europe, and elsewhere as well (Ireland for instance). New borders implied new barriers to trade, including in many cases quantitative restrictions of one sort or another. They also created revanchist feelings, for example in relation to Poland.

The one hope for the reparation of world trade relations was that a major attempt at multilateralism was taken with the establishment of the League of Nations. Yet the League had 
no independent powers and faced a host of problems in trying to re-establish a liberal international trading regime. The accumulation of wartime trade restrictions created obstacles to their removal. Wartime disruptions to trade had created import substituting industries in several countries, and led to an overhang of primary commodities in world markets in the 1920s: both created new protectionist constituencies in several countries. The proliferation of new instruments of trade policy took time to work down, including quantitative restrictions, exchange controls, license requirements, and so forth.

Furthermore, whereas Britain had anchored the nineteenth century order - keeping its market open, practicing non-discrimination, and ensuring that the seas were free - it was now weakened and no longer could serve in that role. The United States, as the new dominant economy, failed to step up and fill the vacuum and remained passively closed by imposing the Fordney-McCumber tariff of 1922 and immigration restrictions. Thus, a weakened United Kingdom was no longer able to provide the global public goods which it had previously done, and the United States was unwilling to pick up the baton (Kindleberger 1973).

The difficulties in restoring monetary and financial stability in the 1920s (countries returned to the gold standard only by the middle or end of the decade) prevented much attention from being focused on trade policy. The World Economic Conference of 1927 was the first attempt to see what might be done by way of multilateral action to restore the MFN clause to its former status and to explore whether some trade liberalization might be feasible. However, any movement down this road was cut short by the start of a recession in 1929 and the failure of the United States, which was not a member of the League, to contribute much to the effort.

In fact, the United States had a destructive influence. Still suffering from the after-effects of World War I, the American agricultural sector pressed for what eventually became the Smoot- 
Hawley tariff in 1930. This tariff hike poisoned international trade relations as other countries resented the fact that the world's largest creditor was hindering the ability of European countries to earn the dollars they needed to pay back war loans and reparations. Other countries retaliated against the United States, and the American move triggered a move toward preferential trade blocs. Having lost some of its access to the U.S. market, Canada turned to secure its access to the markets of Britain and the empire. This gave impetus to the Ottawa agreements in 1932, which established imperial preferences, and pushed the world trading system further away from being a true multilateral system (Table 1).

\begin{tabular}{|c|c|c|c|c|c|c|c|}
\hline \multirow{2}{*}{ Trade of } & \multirow[b]{2}{*}{ Share of } & \multicolumn{3}{|c|}{ In imports } & \multicolumn{3}{|c|}{ In exports } \\
\hline & & 1929 & 1932 & 1938 & 1929 & 1932 & 1938 \\
\hline United Kingdom & $\begin{array}{l}\text { British Commonwealth, colonies, } \\
\text { protectorates, etc. }\end{array}$ & 30.2 & 36.4 & 41.9 & 44.4 & 45.4 & 49.9 \\
\hline United States & Phillippines & 2.9 & 6.1 & 4.8 & 1.6 & 2.8 & 2.8 \\
\hline France & $\begin{array}{l}\text { French colonies, protectorates and } \\
\text { mandated territories }\end{array}$ & 12 & 20.9 & 25.8 & 18.8 & 31.5 & 27.5 \\
\hline Belgium & Belgian Congo & 3.9 & 3.8 & 8.3 & 2.6 & 1.3 & 1.9 \\
\hline Netherlands & Netherlands overseas territories & 5.5 & 5 & 8.8 & 9.4 & 5.9 & 10.7 \\
\hline Italy & Italian colonies and Ethiopia & 1.5 & 1.1 & 1.8 & 2.1 & 3.6 & 23.3 \\
\hline Portugal & Portuguese overseas territories & 7.9 & 10.4 & 10.2 & 12.7 & 13.9 & 12.2 \\
\hline \multirow[t]{5}{*}{ Japan } & Korea and Formosa & 12.3 & 26.2 & 30 & 16.8 & 21.6 & 32.9 \\
\hline & Kwantung & 6 & 4 & 1.6 & 4.8 & 6.8 & 13.7 \\
\hline & Manchuria & 1.9 & 2.7 & 9 & 2.5 & 1.5 & 8.1 \\
\hline & Rest of China & 5.8 & 4 & 4.4 & 10.9 & 7.3 & 8 \\
\hline & Total Japanese sphere of influence & 26 & 36.9 & 45 & 35 & 37.2 & 62.7 \\
\hline \multirow[t]{4}{*}{ Germany } & Bulgaria, Greece, Hungary, & & & & & & \\
\hline & Romania, Turkey, Yugoslavia & 4.5 & 5.5 & 12 & 5 & 3.9 & 13.2 \\
\hline & Latin America & 12.2 & 11.2 & 15.6 & 7.8 & 4.3 & 11.5 \\
\hline & Total German sphere of influence & 16.7 & 16.7 & 27.6 & 12.8 & 8.2 & 24.7 \\
\hline
\end{tabular}

Table 1. The share of formal and informal empire trade, 1929-1938 (percent)

Source: League of Nations (1939), pp. 34-5.

The Great Depression led to further international economic disintegration. As in the 1870s, governments had very few alternative policies to address the economic slump. Monetary 
policy was tied down by the gold standard, and fiscal policy was geared toward balanced budgets in this pre-Keynesian period. With no formal world trade system in place, and with few trade agreements in existence, trade policy was left untethered to any explicit treaty-bound rules and unbound by any strong convictions in favor of open trade. Modern scholarship denies the argument that protection made the Depression Great; rather, the chain of causation runs from the gold standard constraint and flawed monetary policies to the Depression, and then to protectionism. In countries where adherence to the gold standard was most prolonged, the Depression was most prolonged as well. It is in these countries that the resort to higher tariff barriers and quantitative restrictions on trade was most pronounced (Eichengreen and Irwin 2010, Irwin 2012). The non-tariff barriers that arose during this period, including quotas and foreign exchange allocation, to say nothing of clearing arrangements, were inherently discriminatory and further detracted from an open multilateral system.

The nineteenth century system showed that non-discrimination (MFN) could exist without a multilateral institutional framework, but that such a system would not necessarily be one of low trade barriers. The interwar period showed that, without a multilateral framework, the world trading system could be one of high trade barriers and rampant discrimination. In the face of an enormous macroeconomic shock, and when alternative policy instruments were constrained, it was all too easy for countries to resort to protectionism.

\section{The Postwar Period}

The one glimmer of hope in the otherwise depressing 1930s was the slow U.S. retreat from isolationism. In terms of trade policy, this was made evident by the passage of the Reciprocal Trade Agreements Act of 1934. This act delegated to the president tariff negotiating 
power that previous executives had lacked. While the United States concluded nearly two dozen bilateral trade agreements, they did little to reduce trade barriers and stimulate trade in the 1930s. Still, the Roosevelt administration used it as part of its postwar plans to establish a multilateral General Agreement on Tariffs and Trade (GATT) in 1947. Furthermore, it helped establish an international monetary system that proved to be much more flexible than the old gold standard (Gardner 1956). Under the Bretton Woods system, countries tied their currency to the dollar, which was constantly growing in supply (unlike gold, whose growth rate was uncertain), and they were allowed to devalue their currency when balance of problems arose.

The GATT sought to reestablish the central role of the MFN clause in international trade relations. It also sought other rules to constrain the use of trade interventions, such as limits on the use of quotas and regulations on administered protection (the escape clause, antidumping and countervailing duties). The principle of reciprocity in trade negotiations was established. Yet efforts to reduce tariffs came only sporadically. After the initial tariff reductions negotiated in 1947 when the GATT was formed, it took nearly two decades until the next major reductions took place (after the Kennedy Round in 1967). Then it took nearly three decades for the next major round to conclude (the Uruguay Round in 1994).

The postwar period was quite different from the nineteenth century and the interwar epoch in terms of the role of the state in the economy. By this time, countries faced fewer fiscal constraints. The rise of the welfare state dampened demands for protectionist trade policies as there were other means for domestic constituencies to obtain relief. Many industries were nationalized and received government subsidies.

The GATT and WTO texts read as if they are formidable documents, but in fact the rules are elastic in themselves and have been applied with even greater elasticity. While supposedly 
banning import quotas and binding tariff levels, the GATT also allows antidumping and countervailing duties and includes the escape clause, all giving policymakers easy access to measures that can restrict trade. Voluntary export restraints were overlooked. The GATT even oversaw the Multifiber Arrangement (MFA), a global web of product-specific, bilateral restrictions on trade in clothing and apparel. While supposedly mandating unconditional MFN, the GATT system has also allowed for preferential and regional arrangements that reduce trade barriers among a subset of members. While the GATT calls for trade negotiations to be held "from time to time" to reduce trade barriers, much of the postwar liberalization of trade has taken place outside the GATT (the European Common Market, the North American Free Trade Agreement) or on a unilateral basis (Japan, India, China, to name but a few).

The postwar era saw radically different trends in different parts of the world. The familiar story of European integration and trade liberalization under the auspices of the GATT is a regional one, and applied where the United States provided the leadership and global public goods which had once been provided by Britain. While these regions underwent impressive reintegration, after the breakdowns of the interwar period, the story was different elsewhere. The spread of Communism into China and Eastern Europe was one countervailing anti-globalization force; so was decolonization. Import-substituting industrialization strategies, exchange controls, and state monopoly trading boards are as much a part of the postwar scene as successive GATT rounds, until the 1980s and 1990s. That is when China, India and much of the rest of the developing world opened up to foreign trade, with the results we see today. 


\section{Responding to Shocks and Shifts}

This sketch of the broad contours of the world trading system in the past gives us a sense of the strengths and weaknesses of various arrangements. We now turn to how each period has responded to the challenges that have confronted it.

We focus on two types of challenges: shocks and shifts. Shocks are sudden, usually temporary, jolts to international trade or the world economy. Shocks include financial crises and severe recessions that create domestic economic problems, and can also be wars, which are directly disruptive of trade. Shifts play out over a longer time horizon and are usually more permanent. Shifts can be long-run changes in world trade due to evolving comparative advantage and the opening of new markets. These are potentially disruptive to the status quo and may elicit a protectionist response as a way of easing the adjustment costs to a new situation. We will look at the major shocks and shifts affecting the world economy and ask whether or not they led to structural transformations in the nature of the international trading system - both promultilateral and anti-multilateral.

\section{Shocks}

Financial shocks and recessions are easily identified because they have an immediate and visible impact on world trade flows. Figure 3 presents the volume of world trade from 1850 to 2010 (in log scale). In considering international trade in the long run, the first thing to note is that the volume of world trade has increased secularly for nearly two centuries with little interruption. While some small dips are evident in the figure, focusing exclusively on the fluctuations would miss the big picture: despite temporary setbacks due to crises, world trade 
has consistently expanded over time. The two big gaps in the figure reflect World War I and

World War II, when trade was severely disrupted and continuous, comparable data do not exist.

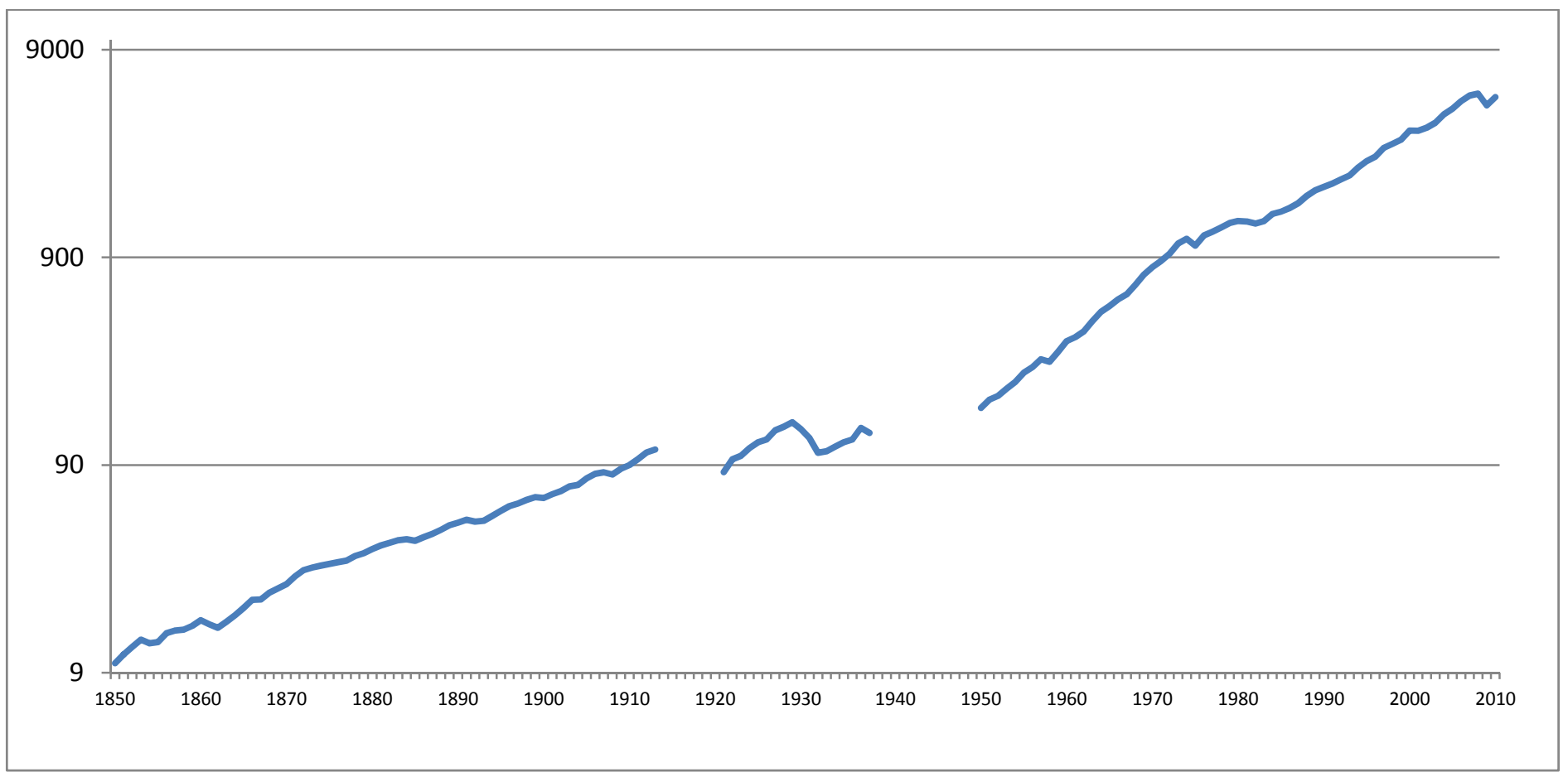

Figure 3. The Volume of World Trade, 1850-2010

Sources: Lewis (1981), United Nations (1962), World Trade Organization.

Figure 4 presents the annual percentage change in the volume of world trade. Over the past 160 years, there have only been 16 years - excluding world wars - in which the volume of world trade fell. The longest and most severe fall was during the three years of the Great Depression (1930-32). In two other periods, trade volumes declined in two consecutive years (1861-62, 1981-82), but to a much smaller degree. The remaining 11 instances were single year declines in world trade, the most significant of which were 2009, 1974, and 1937. 


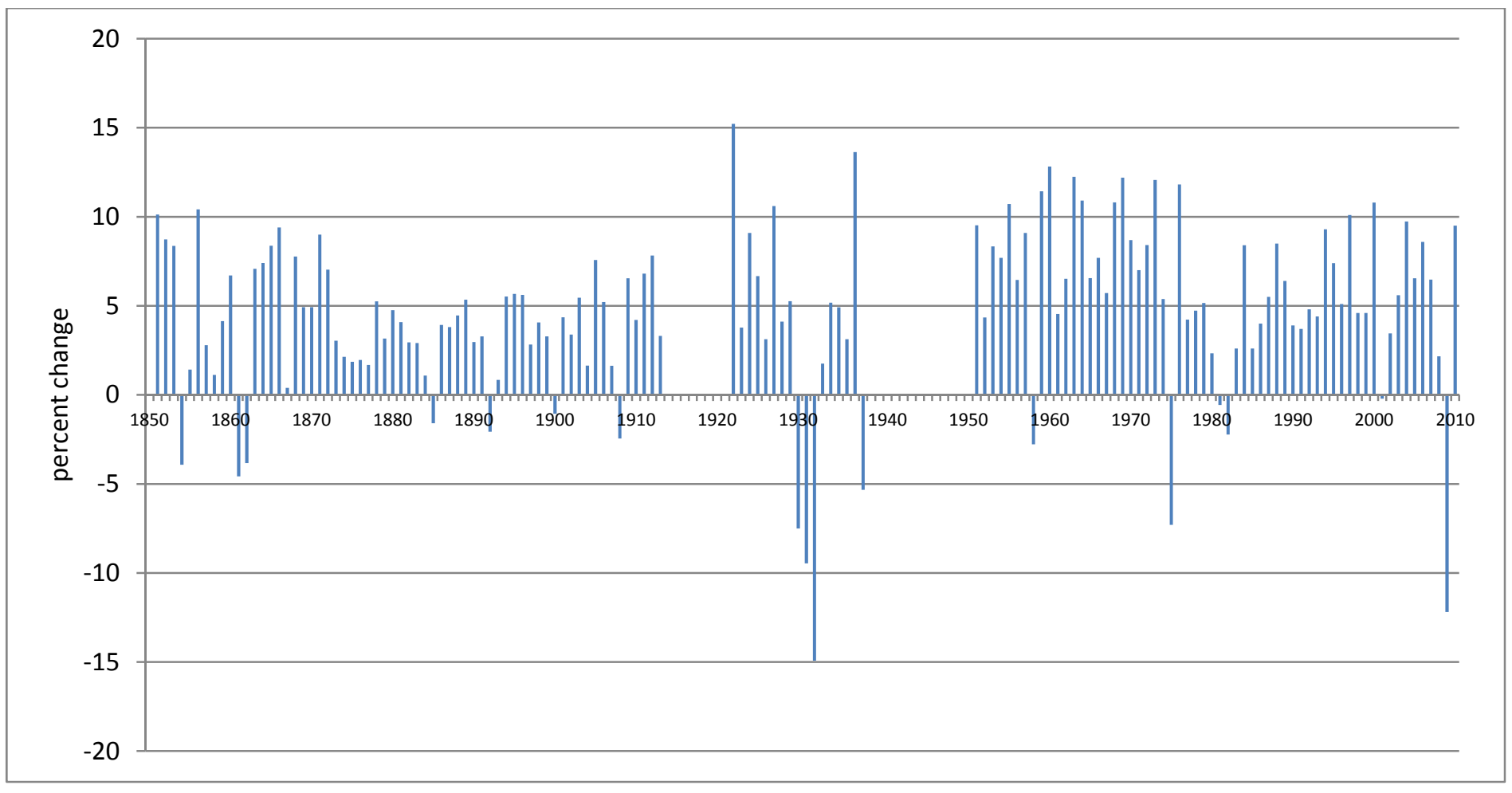

Figure 4. Percentage Change in World Trade Volume, 1850-2010

Sources: See Figure 3.

Table 2 lists all of the recorded declines in world trade volume and our attempts to categorize the underlying shock that caused the decline. The disruptions to world trade tend to fall into one of two broad categories: wars and recessions. Wars can be separated into global or regional conflicts, and recessions can be separated into those associated with a financial panic or banking crisis, and the rest (usually due to a monetary shock). 


\begin{tabular}{|l|l|c|l|}
\hline Name & $\begin{array}{l}\text { Year(s) of } \\
\text { Trade Decline }\end{array}$ & $\begin{array}{c}\text { Decline in Trade } \\
\text { (percent) }\end{array}$ & Type \\
\hline & 1854 & -3.9 & \\
\hline U.S. Civil War & $1861-62$ & -8.2 & Regional war \\
\hline Barings Crisis & 1885 & -1.6 & Recession \\
\hline & 1892 & -2.1 & Financial crisis/recession \\
\hline Panic of 1907 & 1900 & -1.0 & Recession \\
\hline World War I & 1908 & -2.5 & Financial crisis \\
\hline Great Depression & $1914-18$ & n.a. & Global War \\
\hline Recession of 1937 & $1930-32$ & -28.8 & Financial crisis/Recession \\
\hline World War II & 1938 & -5.3 & Recession \\
\hline U.S. Recession & $1939-45$ & n.a. & Global War \\
\hline OPEC oil shock & 1958 & -2.8 & Recession \\
\hline Volcker disinflation & 1974 & -7.3 & Regional war \\
\hline Internet stock bubble & 2001 & -2.8 & Recession \\
\hline U.S. housing bubble & 2009 & -0.2 & Financial crisis/recession \\
\hline
\end{tabular}

Table 2. Declines in World Trade Volume since 1850

Over this period, there were two global wars (World Wars I and II) and two regional wars (the U.S. Civil War and the Yom Kippur War) associated with absolute declines in world trade. The global wars clearly had a major impact on trade: Glick and Taylor (2010) estimate that the reductions in world trade due to World War I were of the order of 30 percent, and that those due to World War II were as much as 50 percent.

The two regional wars that were large enough to bring down aggregate world trade volumes were the U.S. Civil War (in 1861-65) and the Yom Kippur War (in 1973). While the belligerents involved only a few countries, both conflicts constituted sizeable "real" shocks to the 
world economy, enough to have significant consequences for world trade, which fell about 7-8 percent in both cases. In both cases, the wars disrupted the world supply of an important intermediate good. The North's blockade of the South during the American Civil War slashed U.S. cotton exports, a key input to British textile mills. In 1973-74, following the Arab oil embargo as a result of the Yom Kippur War of October 1973, the world economy was tipped into a recession by a sharp rise in the price of petroleum.

Most declines in world trade can be traced to recessions. Of course, a recession in any single country would have a disruptive effect on that country's trade, but not necessarily on world trade as a whole. Recessions striking several large countries simultaneously are those most likely to reduce total world trade, and these are often associated with world financial crises.

Although not all recessions are associated with a major financial panic or banking crisis, the most severe recessions usually are. ${ }^{6}$ The declines in 1892, 1908, 1930-32, and 2009 were associated with financial or banking crises on a global scale. The integration of world capital markets helped ensure that the Barings Crisis of 1891 had international ramifications. Similarly, the Panic of 1907 affected capital markets around the world. Yet not all major financial crises have resulted in a decline in world trade. For example, the world experienced a fairly severe financial crisis in 1873, yet this never led to a decline in world trade volume, although it only grew slowly from 1875-78.

By contrast, the declines in 1854, 1885, 1900, 1938, 1958, 1981-82 are not associated with a financial crisis (although there may have been financial distress, particularly in 1981-82). These recessions are largely due to monetary shocks, the most obvious case being the Volcker disinflation policy in the United States in the early 1980s.

\footnotetext{
${ }^{6}$ For a listing and dating of world financial crises, see Bordo et al. 2001.
} 
From our understanding of these financial crises and recessions, it seems appropriate to view them as exogenous to world trade and commercial policy. The question then is which of these shocks to the trading system had temporary or permanent effects on trade policies. Our evidence is impressionistic, mainly because we lack adequate time-series data on trade policy measures over time.

The two regional wars produced a significant fall in world trade but did not have a major impact on trade policy. However, global wars have proven to be bad for trade and bad for trade policy. Global wars involve extensive government restrictions on trade. Some restrictions are aimed at protecting domestic firms that are producing essential war material, or limit exports of food or natural resources of strategic value. Other restrictions are more pervasive and seek to limit spending on all foreign goods to conserve foreign exchange or gold reserves for national security reasons. Whatever the rationale, such trade restrictions are usually difficult to remove after the war because of the special interests that grow up behind them and have a stake in perpetuating them. In addition, the extensive disruption of markets and the uncertainty about postwar trade flows make governments cautious about pursuing trade liberalization.

Furthermore, establishing a sound international payments system after the war usually takes priority over new international trade arrangements. After World War I, it took countries many years before they returned to the gold standard (Britain was among the first in 1925), after which the League of Nations began to consider addressing trade policy problems. After World War II, the Bretton Woods conference establishing rules for the international monetary system took place well before the formation of the GATT, while it was much easier for GATT to deliver meaningful tariff cuts once currency convertibility had been restored in 1958. 
However, global wars also create opportunities for new trade arrangements. Wars affect the international distribution of power and can shift power towards countries that want a more open system, or not. As we saw in the previous section, World War I ended with a dominant power (the United States) that was unwilling to engage in multilateral negotiations on trade policy. World War II ended with one dominant power, again the United States, that was now willing to engage in multilateral negotiations on trade policy. However, another dominant power, the Soviet Union, had an economic system that was antithetical to open, multilateral trade, and it took its satellites with it in establishing a separate system.

To the extent that most recessions are short and mild, they do not have a major immediate impact on trade policy. The recessions of 1885, 1900, 1908, 1938, and 1958 did not produce major changes in trade policy or result in significant trade protectionism. (The recessions of 1885 and 1900, however, were the impetus for tariff revisions in some countries.)

Of course, the Great Depression of 1929-33 did have a significant impact on trade policy. As we have seen, the monetary and financial problems of the era manifested themselves in a whole host of new trade policy instruments (such as import quotas and import licenses) that seemed to become a permanent feature of world trade. In addition, the period saw the rise of discriminatory trade arrangements, notably imperial preferences. The motivation of such arrangements was not only to guarantee market access, but to conserve on the hard currency needed to make international payments (hence the sterling area, the reichsmark area, etc.). In turn, trade-related disputes were one factor poisoning international relations in the years leading up to World War II.

In sum, shocks that emanate from brief financial crises tend to be transitory and have little long-run affect on trade policy, whereas those that play out over longer periods (early 
1890s, early 1930s) may give rise to protectionism that is difficult to reverse. Regional wars also produce transitory shocks that have little impact on long-run trade policy, while global wars give rise to extensive government trade restrictions that can be difficult to reverse.

Shifts

Thus far we have identified sharp shocks to the international trading system associated with wars and financial crises. There are other disruptions to the international economy that we also want to take into account, which are more slow-moving, but which can have more profound consequences in the long run. We call these shifts and they are of two types: shifts in comparative advantage that change trade flows, and shifts in geopolitical equilibrium that change the trade policies of leading countries.

The first is shifts in comparative advantage. The opening of new markets can change trade patterns and force countries to adjust to the new source of goods. These can take place as a result of transport cost declines, as in the late $19^{\text {th }}$ century: a region such as Prussia, for example, which had been land-abundant in the context of Europe, now found itself faced with competition from the even more land-abundant frontier economies of the New World. Not surprisingly, Prussia’s Junkers switched from being supporters of free trade to being ardent protectionists. China's decision to open itself to international trade in the late $20^{\text {th }}$ century similarly meant that other economies which had traditionally been labor-abundant, such as Portugal or Mexico, now found that their comparative advantage in labor-intensive industries such as textiles was now being eroded.

Shifts in comparative advantage can also take place as a result of technological diffusion, and in particular the spread of modern industry around the world. Britain steadily lost 
comparative advantage in a variety of industrial activities in the late $19^{\text {th }}$ and early $20^{\text {th }}$ centuries, as other countries - and particularly Germany and the United States - caught up with her and became major industrial powers. The rise of Japan in the 1980s also caused shifts in comparative advantage in certain industries, and the rise of China is doing the same today.

Sometimes these shifts elicit a protectionist backlash. The shift in comparative advantage associated with the opening up of New World frontiers, and the subsequent "grain invasion" of Europe, led to higher agricultural tariffs from the late 1870s onwards, which as we have seen reversed the moved towards freer trade which had characterized mid-nineteenth century Europe. In the decades after World War II, Japan's rapid rise led to trade friction with other countries. Japan's recovery was accompanied by a sharp increase in its exports of certain product categories, cotton textiles in the 1950s, steel in the 1960s, automobiles in the 1970s, and electronics in the 1980s. In each case, the rapid expansion in Japan's exports created difficulties for its trading partners and the use of protectionism as a shock absorber. Exports of cotton textiles led to the Short-term and Long-term Trade Arrangement with the United States, capping the growth rate of its textile exports, and eventually the multilateral Multi-Fiber Arrangement (MFA) that spread to encompass developing countries across Asia. Steel and automobile exports led to voluntary export restraints in the 1970s and 1980s, and antidumping and countervailing duties limited Japan’s exports of electronics.

One factor that may influence the trade policy response to such a situation is the speed with which the change in comparative advantage affects domestic producers. If the costs of dislocation are high, political support for open trade will falter. If the costs of adjustment are relatively low or are spread out over many decades, open trade may continue unhindered. 
On the other hand, perhaps the most remarkable achievement of the trading system in recent years has been the reintegration of Eastern Europe and the former Soviet Union into world trade, as well as the accommodation of China. Given the phenomenal growth rate of exports from China, it is surprising that this has not led to more of a protectionist backlash. One reason is that China started by exporting labor-intensive manufactured goods, such as textiles, which were (largely) no longer produced in the United States, Japan, and Western Europe. Given that these countries already imported such goods from other Asian countries, the domestic disruption was minimal. Second, Western producer interests were largely favorable to the new trade flows, since they were themselves involved in the flow, as a result of the outsourcing of production in the 1990s and 2000s. Third, the international trading system was flexible enough that countries could temporarily protect their markets without overturning the entire system: one such example came in 2005, when the MFA lapsed, and was promptly replaced by moves in Europe and the United States to limit imports of Chinese textiles. And fourth, postwar Western economies have benefited from social safety nets that could shelter displaced workers, at least to some extent, from the consequences of import competition.

A second type of long run shift which may have profound implications for the international trading system is shifts in the geopolitical equilibrium. One such shift was provoked by the unification and industrialization of Germany, which made unsustainable the post-1815 settlement whereby Britain was the dominant power in Western Europe and the dominant sea power as well. When a leading power, particularly one interested in an open trading system, such as the United Kingdom in the $19^{\text {th }}$ century and the United States in the late $20^{\text {th }}$ century, is no longer the dominant influence in world politics, open trade policies may suffer. As we know, the 
international system did not cope well with the early $20^{\text {th }}$ century geopolitical shock of a diminished Britain and a rising Germany and Japan.

The 'diminished giant syndrome’ can lead to demands for protection, such as Joseph Chamberlain’s call for Tariff Reform in Britain in the early years of the twentieth century (Bhagwati and Irwin 1987). In this case, however, these calls would only be acted upon when the Great Depression hit. After World War II, the United States emerged in such a dominant position, with other countries devastated from the war, that domestic producers faced little foreign competition. The recovery of Europe was gradual enough that there were no major disruptions to domestic producers.

We are currently living through another major shift in the world economy with the rise of China and India today. This is making untenable both the unipolar world of the post-Cold War era, and its bipolar predecessor. How the world adjusts to this shift in the balance of power will be one of the main questions of the twenty-first century, and will have major implications for the future of globalization.

\section{The importance of shock absorbers}

On the face of it, it seems as though there were several reasons to be worried about the future of the international trading system in 2008 and 2009. The world economy was subjected to an enormous international financial crisis, which during its first year saw global industrial production falling at Great Depression rates, and world trade falling even faster (Eichengreen and O’Rourke 2009). Furthermore, this shock was superimposed upon a major long term shift in comparative advantage, as labor-intensive Asian manufactures displaced production in the West. Whether and to what extent unskilled labor in the West was harmed by this is a matter of debate, 
but what has been clear for some time is that less skilled workers in the West are more hostile towards globalization than the more highly skilled (Scheve and Slaughter 2001, Mayda and Rodrik 2005, O’Rourke and Sinnott 2001).

Furthermore, in Europe this hostility manifested itself in a very concrete fashion with the French and Irish rejections of European constitutional reform in 2005 and 2008, while in several countries today populist parties are appealing to blue collar workers' suspicions of open international markets and international elites. As noted earlier, it took the shock of the Great Depression to turn anti-trade sentiments aroused by the shift in economic power away from the Britain into concrete protectionist action there. Might the shock-cum-shift of 2008 have led to the same outcome?

This hasn't happened to date, and the major reason is that today's shock absorbers have been better developed than those of the 1930s. In terms of macroeconomics, the major difference has been between the constraints of the classical gold standard, on the one hand, and the flexibility of monetary policy implied by floating exchange rates on the other. As long as interwar governments remained tied to gold, they were unable to use countercyclical fiscal or monetary policy to combat the Depression; indeed policy was often pro-cyclical, as in the case of the fiscal policies of the dying Weimar Republic, or the interest rate increases which occurred in several countries in 1931-2. In 2008-9, by contrast, interest rates were aggressively lowered, some central banks engaged in quantitative easing, automatic stabilizers were for the most part allowed to operate, and there was some limited, if poorly targeted, fiscal stimulus. In those countries where fiscal policy was pro-cyclical, such as Ireland or Latvia, output fell at Great Depression rates, but these countries were too small to matter globally. The result was that recovery began after just one year, while during the Great Depression activity contracted for 
several years. This prolonged economic slide is what did the damage politically, both domestically and internationally.

Other shock absorbers are also better developed today. Modern welfare states in Europe and elsewhere mean that people who become unemployed do not find themselves immediately hungry and homeless, as was the case in the 1930s. States provide insurance policies to workers facing market risks, either via explicit social insurance programs, or simply because of the share of national economic activity which they represent (Rodrik 1998). And, as stressed earlier, today's multilateral institutions not only provide a framework which helps to lock in openness, but themselves provide an element of flexibility to states which allows them to respond to particularly adverse circumstances without walking away from their international obligations altogether.

The rules of the trading system are also important in promoting geopolitical stability. The post-World War II international trading system was based on the GATT and the Bretton Woods institutions, but more fundamentally it was based on the principle embodied in the Atlantic Charter whereby the United States and Britain would "endeavor, with due respect for their existing obligations, to further the enjoyment by all States, great or small, victor or vanquished, of access, on equal terms, to the trade and to the raw materials of the world which are needed for their economic prosperity.” (Of course this principle was waived in the case of both cold and hot wars in the late $20^{\text {th }}$ century.) This dimension of multilateralism relies on - and promotes - the confidence of countries that they can rely on the market to provide them with essential food and raw materials: a confidence that was notably absent in Wilhelmine Germany and interwar Japan, with destabilizing and tragic consequences. Moves by several countries to carve out sources of exclusive supply of grains or other commodities in recent years indicate a 
decline in such confidence, but it is essential that it be maintained; for the belief in an open international trading system is the ultimate geopolitical shock absorber.

\section{Conclusions}

This paper has provided a historical look at the multilateral trading system and its resilience in the face of various shocks. We contrasted four different periods: the non-system of the mercantilist period, the informal nineteenth century treaty network, the non-system of the interwar period, and the post-World War II period of the GATT and WTO. The nineteenth century network was an open system in which the MFN clause was widely used, but the system could not maintain low trade barriers in the face of various economic shocks and long-term shifts in comparative advantage. An interwar system never had the chance to develop following the disruption of World War I, and whatever remained of the liberal system - non-discrimination and moderate trade barriers - was destroyed in the Great Depression. From the ashes of the Depression and World War II came, for the first time, a multilateral system with rules about trade policy (including MFN) and negotiations about trade barriers. The system has shown its worth since 2008, when despite a major economic crisis it has been flexible and resilient enough to remain intact.

We have distinguished between shocks and shifts and the ways in which the trading system has coped with each. Shocks are short-term problems arising from financial crises or wars, whereas shifts can be long-term changes in comparative advantage, perhaps due to the opening of new markets. In terms of the trade policy reaction, shocks tend to be benign, except in the case of a major war or prolonged economic crisis, whereas shifts often pose more difficult challenges for open trade. For example, many observers have been surprised that the global 
financial crisis in 2008-09 did not result in much protectionism. Yet in light of our discussion of history, this outcome should not have been too surprising. Previous panics and crises have produced significant declines in world trade with little or no change in trade policies (the Panic of 1907 comes to mind). The drop in trade, which was much steeper than the decline in domestic output, meant that demands for protectionism remained muted. In addition, as stressed above, today's world economy possesses a number of shock absorbers which were absent in the 1930s. Among these are superior macroeconomic shock absorbers, particularly the independent monetary policies that come with the flexible exchange rate regime that operates at the global level (but not at the European one). ${ }^{7}$

The greater challenge in coming decades will be the shift in world economic activity toward Asia, China and India in particular. Like a movement in the earth’s tectonic plates, this has already created friction with the West. The relative decline of the West and rise of the rest is bound to characterize the coming century. As mentioned earlier, the response of the international system to the rise of Germany and Japan in the early $20^{\text {th }}$ century was hardly a successful one. Whether the Western economies are flexible enough, and international institutions such as the WTO robust enough, to accommodate this historic change in the world economy is the great question for the $21^{\text {st }}$ century.

\footnotetext{
${ }^{7}$ See Bown (2011) for a review of the trade policy response to the recent crisis, and Irwin (2012) for a comparison with the 1930s.
} 


\section{References}

Anonymous. 1919. The Aesop for Children. Chicago: Rand McNally. Available at http://www.gutenberg.org/files/19994/19994-h/19994-h.htm\#Page_32

Bagwell, Kyle, and Robert W. Staiger. 2002. The Economics of the World Trading System. Cambridge: MIT Press.

Bhagwati, Jagdish, and Douglas A. Irwin. 1987. "The Return of the Reciprocitarians: U.S. Trade Policy Today.” The World Economy.

Bordo, Michael, Barry Eichengreen, Daniela Klingebiel and Maria Soledad Martinez-Peria. 2001. “Is the Crisis Problem Growing More Severe?” Economic Policy 16: 53-82.

Bown, Chad (ed.). 2011. The Great Recession and Import Protection: The Role of Temporary Trade Barriers. Washington, D.C.: The World Bank.

Eichengreen, Barry. 1992. Golden Fetters: The Gold Standard and the Great Depression 19191939. Oxford: Oxford University Press.

Eichengreen, Barry and Douglas Irwin. 2010. "The Slide to Protectionism in the Great Depression: Who Succumbed and Why?” Journal of Economic History 70: 871-97.

Eichengreen, B. and Kevin H. O’Rourke. 2009. “A Tale of Two Depressions.” http://www.voxeu.org/index.php?q=node/3421

Ethier, Wilfred. 2004. "Political Externalities, Non-discrimination, and a Multilateral World.” Review of International Economics 12: 303-320.

Findlay, Ronald, and Kevin H. O’Rourke. 2007. Power and Plenty: Trade, War, and the World Economy in the Second Millennium. Princeton: Princeton University Press.

Gardner, Richard N. 1956. Sterling-Dollar Diplomacy: Anglo-American Collaboration in the Reconstruction of Multilateral Trade. Oxford: Clarendon Press.

Gaston, Jack. 1987. “The Free Trade Diplomacy Debate and the Victorian European Common Market Initiative.” Canadian Journal of History, 22: 59-82.

Glick, Reuven., and Alan. M. Taylor. 2010. "Collateral Damage: Trade Disruption and the Economic Impact of War.” Review of Economics and Statistics 92: 102-127.

Huberman, Michael, and Wayne Lewchuk. 2003. "European Economic Integration and the Labour Compact, 1850-1913.” European Review of Economic History 7: 3-41. 
Irwin, Douglas A. 1993. "Multilateral and Bilateral Trade Policies in the World Trading System: An Historical Perspective.” In New Dimensions in Regional Integration, ed. J. de Melo and A. Panagariya. Cambridge: Cambridge University Press.

Irwin, Douglas A. 2012. Trade Policy Disaster: Lesson from the 1930s. Cambridge: MIT Press.

Keohane, Robert O. 1990. “Multilateralism: An Agenda for Research.” International Journal 45: 731-64.

Kindleberger, Charles P. 1973. The World in Depression. Boston: Little, Brown.

Lampe, Markus. 2009. "Effects of Bilateralism and the MFN Clause on International Trade: Evidence for the Cobden-Chevalier Network, 1860-1875.” Journal of Economic History 69: 1012-40.

Lampe, Markus. 2011. "Explaining Nineteenth-Century Bilateralism: Economic and Political Determinants of the Cobden-Chevalier Network.” Economic History Review 64: 644-68.

League of Nations. 1939. Review of World Trade 1938. Geneva: League of Nations.

Lewis, W. Arthur. 1981. “The Rate of Growth of World Trade, 1833-1973.” In The World Economic Order: Past and Prospects, edited by Sven Grassman and Erik Lundberg. New York: St. Martin's.

Maggi, Giovanni and Andres Rodriguez-Clare. 1998. "The Value of Trade Agreements in the Presence of Political Pressures.” Journal of Political Economy 106: 574-601.

Mayda, Anna Maria and Dani Rodrik. 2005. "Why Are Some People (and Countries) More Protectionist than Others?” European Economic Review 49: 1393-1430.

O'Rourke, Kevin H. 1997. “The European Grain Invasion, 1870-1913.” Journal of Economic History 57: 775-801.

O’Rourke, Kevin H. and Richard Sinnott. 2001. "What Determines Attitudes Towards Protection? Some Cross-Country Evidence.” In Brookings Trade Forum 2001, ed. S.M. Collins and D.Rodrik. Washington DC: Brookings Institution Press.

O’Rourke, Kevin H., and Jeffrey G. Williamson. 1999. Globalization and History. Cambridge: MIT Press.

O’Rourke, Kevin H. and Jeffrey G. Williamson. 2002. “When did Globalization Begin?” European Review of Economic History 6: 23-50.

Rodrik, Dani. 1998. “Why Do More Open Economies Have Bigger Governments?” Journal of Political Economy 106: 997-1032. 
Rodrik, Dani. 2011. The Globalization Paradox: Democracy and the Future of the World Economy. New York: Norton.

Saul, S.B. 1960. Studies in British Overseas Trade 1870-1914. Liverpool: Liverpool University Press.

Scheve, Kenneth F. and Matthew J. Slaughter. 2001. "What Determines Individual Trade-Policy Preferences?” Journal of International Economics 54:267-292.

United Nations. 1962. International Trade Statistics 1900-1960. Available at: http://unstats.un.org/unsd/trade/imts/historical_data.htm.

Viner, Jacob. 1948. "Power Versus Plenty as Objectives of Foreign Policy in the Seventeenth and Eighteenth Centuries.” World Politics 1: 1-29. 